(52) 強震記録による

新滔平野の波動伝播の検討

（1990 年新泊県中部地震のケース）

東京電力（株） O植竹富一, 田中英朗

\title{
1.はじめに
}

観測される地震動には，観測点近傍の特性のみならず震源の特性，伝播経路の特性が反映されている．と りわけ，表面波成分が卓越すると考えられるやや長周期帯域の地震動には伝播経路の特性が大きな影響を与 えていると考えられる．地震波の伝播性状は地盤固有の特性であり，地盤が非線形性を示さない範囲におい ては，小さな地震での知見が大地震に対しても成り立つと考えられる．したがって，中小規模の地震につい て地震波の伝播性状を検討し, その知見を蓄積することは大地震時の地震動予測に重要な資料を提供するこ とになる。

新潟地域は1964年新潟地震・1983年日本海中部地震の際にやや長周期の表面波が卓越したことが指摘され

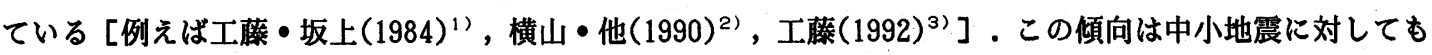
同様であろうか. 植竹 $(1992)^{4)}$ は，1990年12月7日に新潟県中部で発生した地震（M5.4，震源深さ約15km） の地震について新潟県・柏崎におけるトリパタイトアレー記録の解析から, 周期 3〜 8秒において表面波的 な挙動を示す波群が見られることを指摘している．新潟は震央からみて柏崎の延長上に位置していることか ら，同様に表面波群の発達が予想される.今回, 柏崎の記録に加え気象庁87型強震計 ${ }^{5}$ による新潟での記録 及び（財）鉄道総合技術研究所による長岡・川口の加速度記録を用いて地震波の伝播性状を検討し，同地震 による新潟での記録の解釈を試みたのでその結果を報告する。

\section{2. 地震の震央及び地震観測点}

検討に用いた地震の震央及び観測点の分布をFig. 1 に示す．新潟は震央からみてほぼ北北東の方角にあり 震央距離は約 $89 \mathrm{~km}$ である。新潟県 $(1989)^{6)}$ によれば, 震央付近から新潟にいたる地域では新第三紀以降の堆 積層が厚く，震央付近から新潟に向かい厚くなる傾向 にあり，深いところでは厚さ $5 \mathrm{~km}$ を超える．また，特 に信濃川沿いの地域では第四紀層の発達す著しい．

各地点の地震計はTable 1 に示す通りであり,すべ て加速度計である.なお，本検討では $0.1 \sim 10 \mathrm{~Hz}$ の範囲 内で各地震計の特性は同等と見なした。

Table 1 地震計の特性

\begin{tabular}{|l|l|l|l|}
\hline 観測点 & 地震計TYPE & サソプ ツソグ & 周波数範囲 \\
\hline 新潟 & 気象庁87型 & 0.02 秒 & $0.01 \sim 10 \mathrm{~Hz}$ \\
\hline $\begin{array}{l}\text { 長風 } \\
\text { 川口 }\end{array}$ & 明石AJA-5RC & 0.0102 秒 & $0.01 \sim 20 \mathrm{~Hz}$ \\
\hline 柏崎 & 明石AJE-306 & 0.01 秒 & $0.1 \sim 30 \mathrm{~Hz}$ \\
\hline
\end{tabular}

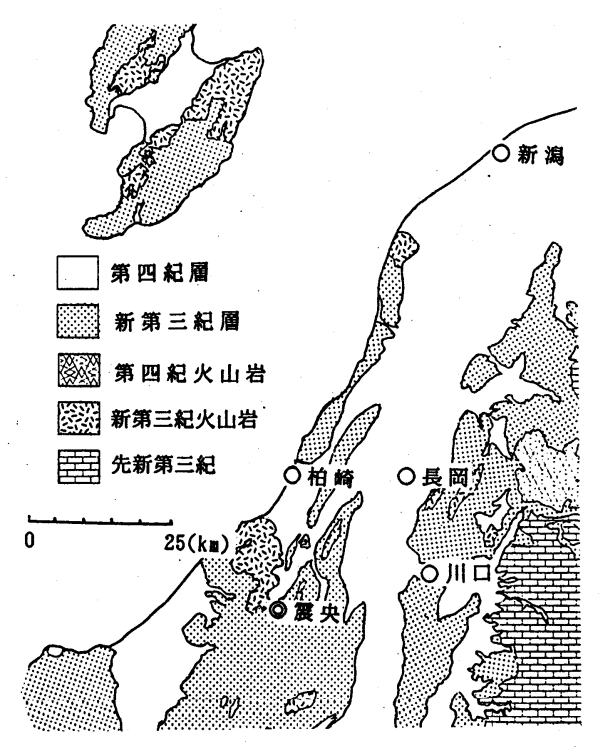

Fig. 1 震央及び観測点 (表層地質は新潟県 $(1989)^{6)}$ による) 

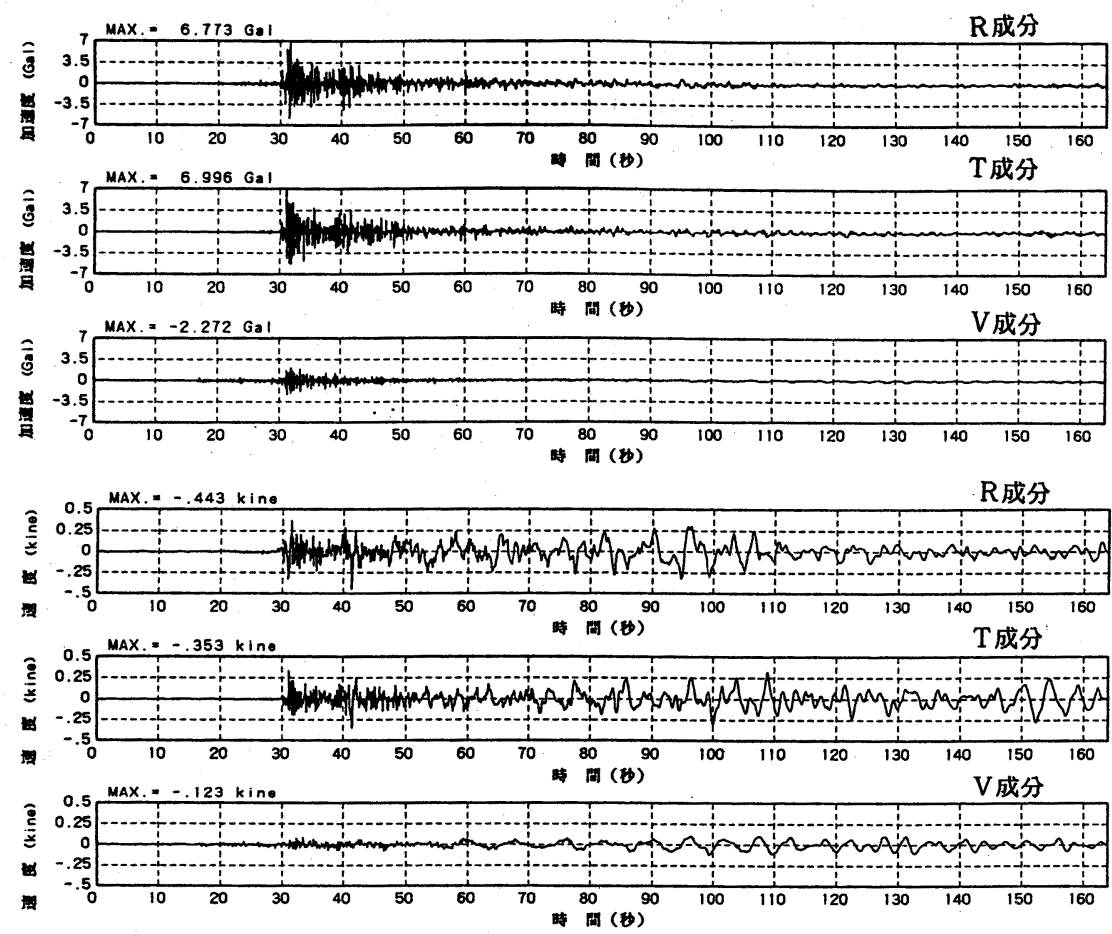

Fig. 2 新潟におけるJMA87型強震計記録（加速度記録及び積分による速度波形(カットオフ周期20秒)）

\section{3. 新潟の記録の特徵}

新潟における加速度波形及び積分によって求めた速 度波形をFig. 2に示す. 水平成分は震源からの方位で ラディアル $(\mathrm{R})$ 成分, トランスバース $(\mathrm{T})$ 成分に 変換してある. マグニチュード（M 5.4）のわりに地 震動の継続時間が長く, 主要動のあとに小振幅ではあ るが長周期の後続波群が続いている.この傾向は速度 波形で見るといっそう顕著であり, 後続の波群の発達 や各成分間の違いがはっきりわかる。また，Fig．3に 新潟及び他の 3 点の記録の加速度フーリエスペクトル を示す. 長周期側の右上がりの傾向でスペクトルの信 頼周期を判断すれば，川口が 5 秒程度までなのを除き， 他の 3 点では10秒程度までは信頼性があると考えられ る. 川口を除く 3 点は比較的長周期までフラットなス ペクトル形状をしており，特に新潟の水平成分では， $\mathrm{R}$ 成分で約 7秒付近， T成分で約 5 秒付近までほとん どレベルが下がらない。また, 新潟の上下成分は, 周 期 3〜 5秒のスペクトルレベルがそれより短周期側よ りむ大きい。一般に，上下動の方が水平動に比べ卓越 周期が短いと言われるが, この記録においてはこの周 期 3〜 5秒での卓越が特徽的である.

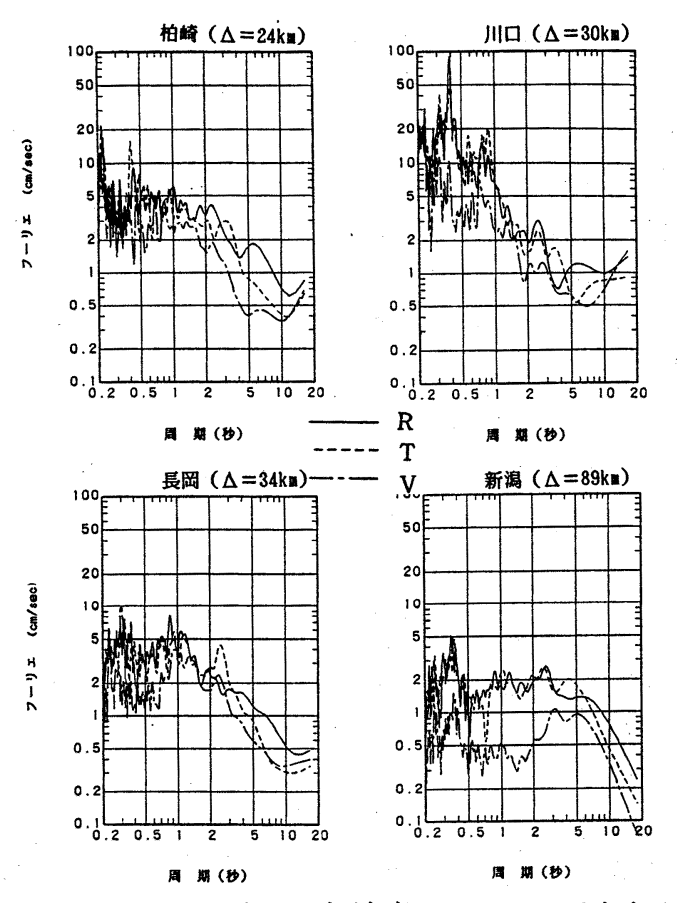

Fig. 3 各観測点での加速度フーリエスペクトル (Parzen 0.1Hzで平滑化) 
次に新潟の記録についてバンドパスフィルターを用 いて分散性を検討した， R成分のバンドパスフィルタ 一波形（中心周期：1〜10秒）をFig. 4に示す. 各周 期とも複数の波群が見られるが，主要な波群について は分散性が羿められ，原波形の最大值発生時刻に比べ かなり遅れて最大振幅を生じている。このような後読 波群の存在がフーリエスペクトルの長周期成分と関連 しているようである。また，Fig，4には植竹 $(1992)^{4)}$ が柏崎の記録の解釈に用いた地下構造モデル（Table 2 ）による表面波（レーリー波基本モード）の到達時 間を記入してある. 周期 5 秒以上については記録の波 群に比べ若干早めではあるが全体的な傾向は一致して いる. Table 2 のモデルは震源付近を対象としたもの であるため，新潟の記録に適合させるためにはモデル の修正が必要と考える。

なお， $\mathrm{T}$ 成分には R成分と異なった分散性が見られ， 波群を構成する波動成分の違いが同える．また，上下 成分にはR成分と同様な分散性が認められた。

\section{4. 波動の伝播}

柏崎, 川口, 長岡及び新潟の加速度記録のバンドパ スフィルター波形についてペーストアップ図を作成し 波群の対応を調べた（Fig．5，6，7）.川口・長岡の 記録については時刻の精度が低いとのことなので,こ れらの図は絶対時刻でなく $\mathrm{S}$ 波初動と考えられる時刻 で基準化してある.これは，どの地点までも同じ速度 で $\mathrm{S}$ 波が伝播したと見なしたことに相当する。なお， 図中に S 波初動が $3 \mathrm{~km} / \mathrm{s}$ で伝播したと考えたときの

$1 \mathrm{~km} / \mathrm{s}$ 及び $0.5 \mathrm{~km} / \mathrm{s}$ の傾きを記入してある． $3 \mathrm{~km} / \mathrm{s}$ と いう速度は柏崎及び新潟の $\mathrm{S}$ 波到達時から見て妥当な 値である. 新潟が他の3点とかなり離れていること及 び記録に複数の波群が見られることから, 波群の笅密 な同定は難しいが，どの図においてす $\mathrm{S}$ 波よりかなり 遅い速度で伝播していると考えられるような波群が存 在する．すべての波群を説明できるわけではないが， 新潟の記録に見られる分散性と合わせて考えれば，後 続波群について表面波の伝播として解釈可能な面があ ると考える。

また，川口は柏崎と長岡の間の距離にあるにす関わ らず若干異なった挙動をしている。これは記録の $\mathrm{S} / \mathrm{N}$ 比の問題に加え，震央からの方位や地下構造が他の地 点と若干異なることに関連すると考えられる。

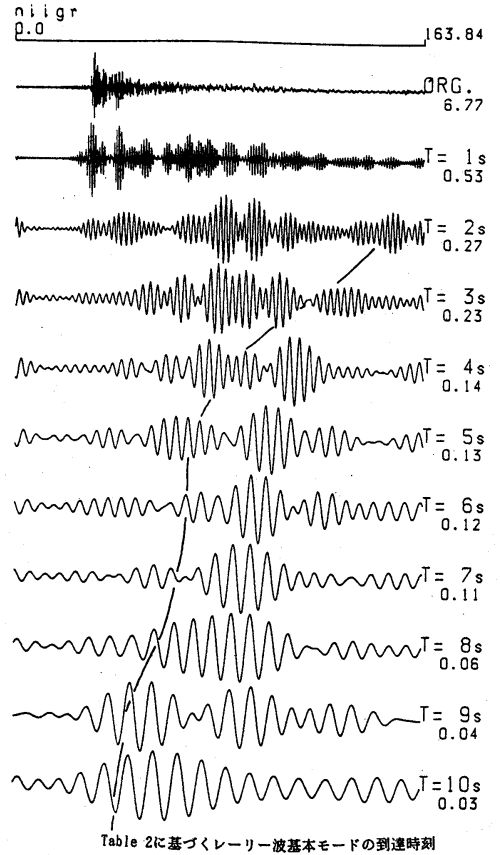

Fig. 4 新潟の記録のバンドパスフィルター波形

Table 2 植竹 $(1992)^{4)}$ の地下構造モデル

\begin{tabular}{ccccc}
\hline $\begin{array}{c}\text { Layer } \\
\text { No. }\end{array}$ & $\begin{array}{c}V_{\mathrm{p}} \\
(\mathrm{km} / \mathrm{s})\end{array}$ & $\begin{array}{c}V_{\mathbf{z}} \\
(\mathrm{km} / \mathrm{s})\end{array}$ & $\begin{array}{c}\rho \\
\left(\mathrm{g} / \mathrm{cm}^{3}\right)\end{array}$ & $\begin{array}{c}\text { Thickness } \\
(\mathrm{km})\end{array}$ \\
\hline 1 & 2.0 & 0.9 & 2.0 & 0.9 \\
2 & 3.1 & 1.6 & 2.2 & 1.5 \\
3 & 4.7 & 2.2 & 2.5 & 4.0 \\
4 & 6.0 & 3.4 & 2.7 & \\
\hline
\end{tabular}

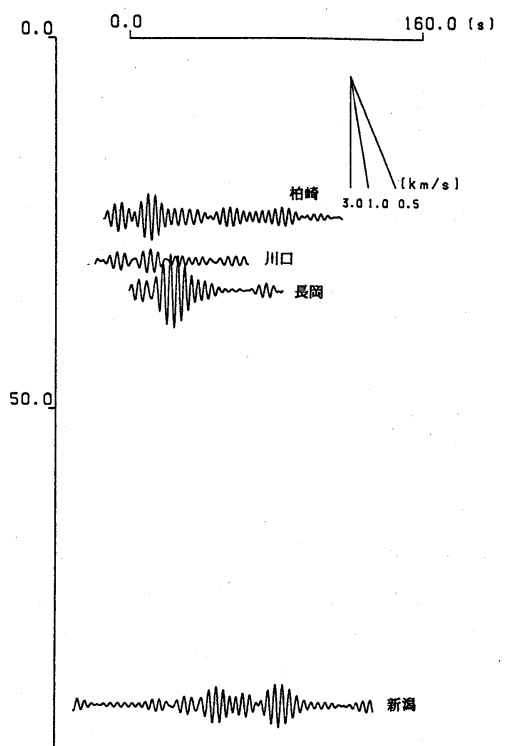

Fig. 5 フィルター波形のペーストアップ ( $\mathrm{R}$ 成分：中心周期 4 秒) 


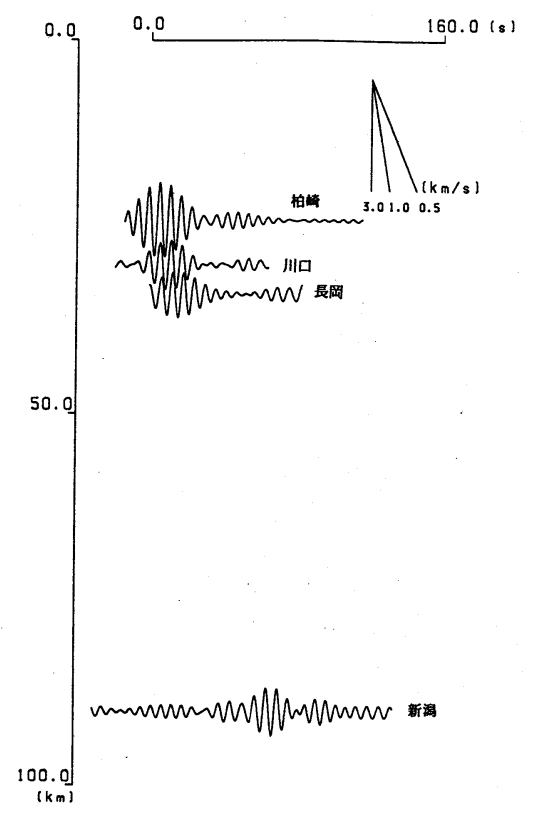

Fig. 6 フィルター波形のペーストアップ ( $\mathrm{R}$ 成分：中心周期 6 秒)

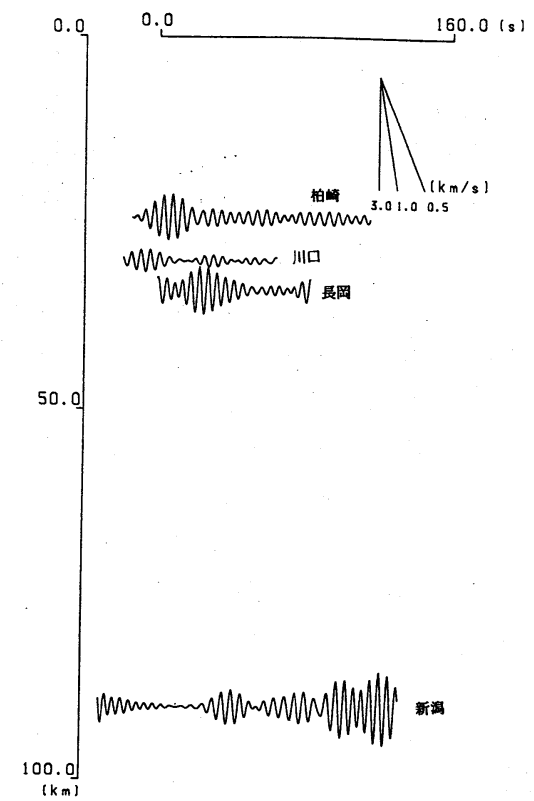

Fig. 7 フィルター波形のペーストアップ

( $\mathrm{T}$ 成分 : 中心周期 5 秒)

\section{5.まとめ}

新潟県中部で発生した中規模地震（M 5.4)の加速度強震記録を用いて，新潟における地震動の特徽を検討 した。その結果以下のことが指摘できる.

新潟ではかなり長周期側まで加速度フーリエスペクトルレベルが落ちない．このことは，長周期の後続波 群の存在と関係がありそうである．後続波群については，震央と新潟を結ぶ線上の観測点の記録からは震央 近くから S 波より遅い速度で伝播すると考えられる波群が見られること，きれいな分散性を示すことなどか ら，この地域の地下構造の特徽を反映した表面波で構成されると考えられる．

今回の結果のような知見を積み重ね, 地震動の特性を理解していくことが，地震動予測の信頼性向上につ ながると考える。

（謝辞） 貴重な記録を提供して頂きました（財）鉄道総合技術研究所・中村豊博士び気象庁関係各位に感 謝致します。

\section{(文献)}

1 ）工藤一嘉・坂上実，1984，1983年日本海中部地震による石油タンク被害と地震動の特徵についてー新潟 における石油溢流の問題点一, 地震研究所彙報, 59, 361-382.

2 ）横山正義・他, 1990 , 日本海中部地震における東北地方各地の気象庁 1 倍変位計記録に関する考察, 第 8 回日本地震工学シンポジウム論文集, 403-408.

3) 工藤一嘉, 1992,1964 年新潟地震, 川岸町における強震記録の再検討, 地震学会講演予稿集No.2, 138 .

4) 植竹富一, 1992 , 新潟県南部の浅発地震によるやや長周期地震動の解析, 地震 $2,45,317-325$.

5 ）若山晶彦・他, 1989 , 気象庁における電磁式強震計観測の現状, 地震学会予稿集, No.1, 115 .

6 ）新潟県, 1989 , 新潟県地質図. 